\title{
DENTOSKELETAL PARAMETERS IN INDIVIDUALS WITH MAXILLARY CANINE DISPLACEMENT (A RETROSPECTIVE STUDY)
}

\author{
Waleed Refaat
}

\begin{abstract}
No studies have been done to measure the skeletal, dentoalveolar and soft tissue parameters in subjects with palatally and buccally displaced canines. The hypothesis of this study is that there is difference in the skeletal and dentoalveolar measurements between subjects with palatally, buccally and normally erupting canines. A total of 200 subjects with maxillary canine displacement (90 palatally displaced, 110 buccally displaced) were recruited for this study. The age of the subjects ranged between 13-15 years old. Subjects were divided into 2 groups (maxillary palatal canine displacement and maxillary buccal canine displacement). These subjects were compared with 100 subjects asa control group. In conclusion,There in is no significant difference in maxillary length between subjects with buccally and palatally displaced canine and control group. However palatal canine displacement group had reduced vertical dimensions, increased overbite, small dentoalveolar heights and retruded upper and lower lips.
\end{abstract}

\section{INTRODUCTION}

The ectopic eruption or the impaction of the maxillary permanent canine is an important frequently faced problem in clinical orthodontics. The maxillary canine tooth is second to mandibular third molar in its frequency of impaction (McSherry and Richardson, 1999) ${ }^{1}$. The reported prevalence varies from 0.8-2.8 per cent (Shah et al., 1978; Grover and Lorton) ${ }^{2}$. The etiology of the impaction is obscure. The early prediction and prevention of maxillary canine impaction should be of fundamental importance to the orthodontist to prevent a more complicated and prolonged treatment (eg, surgical uncovering followed by orthodontic repositioning of the unerupted tooth) or possible detrimental effects such as root resorption of adjacent teeth.

Impacted teeth are those with a delayed eruption time or those that are not expected to erupt completely based on clinical and radiological assessment (Thilander and Jakobsson, 1968) . Another definition of impacted teeth are those that are prevented from eruption by some physical barrier (Suriet al., 2004) ${ }^{4}$ or those that are dislocated from their usual position within the dentoalveolar process with disturbed normal eruption pattern (Peck et al., 1994) $)^{5}$ The ectopic eruption and

* Assistant Professor of Orthodontic, Suez Canal University 
impaction of maxillary permanent canines is a frequently encountered clinical problem. Canine impaction is not a new phenomenon. A case has recently been reported in an excavated skull dated at 2700 to 2724 BC (Rajic et al., 1996) ${ }^{6}$. The impacted canine is placed palatal to the dental arch in 85 per cent of cases and labial/buccal in 15 per cent of cases (Ericson and Kurol, 1987) ${ }^{7}$. In another study by Stivaros and Mandall ${ }^{8}$ in 2000, they reported that the maxillary canine was displaced palatally in $61 \%$ of the cases, within the line of the arch in $34 \%$ and buccally displaced in $5 \%$.

The etiology of the impaction is obscure. The main difference between these two conditions is an altered tooth size-arch length relationship. Crowding is found in a minority of palatally displaced canine cases and most of these cases occur when excess space is available in the dental arch (Jacoby, 1983'; Zilberman et al., 1990% ; Peck et $a l ., 1996)^{10}$. The maxillary canine tooth is second to mandibular third molar in its frequency of impaction (McSherry and Richardson, 1999'; Sambataro et al ., $2005)^{11}$. Moyers $(1963)^{12}$ noted that any tooth can be impacted, but the teeth most frequently involved are the mandibular third molar, the maxillary canine, the mandibular and maxillary second premolars, and the maxillary central incisor, in that order.

Dachi and Howell (1961) $)^{13}$ reported an incidence of $0.92 \%$ for canine impaction, whereas Thilander and Meyrberg (1973) ${ }^{14}$ estimated cumulative prevalence in $7-13$ year olds to be $2.2 \%$. Shah et al. $(1978)^{15}$ reported that prevalence varies from $0.8-2.8$ per cent. Unilateral impaction is much more common than bilateral impaction. Kuftinec et al. $(1995)^{16}$ reported that unilateral canine impactions are more common than bilateral ones by a factor of 5:1. McConnell et al. (1996) ${ }^{17}$ reported that 8 per cent of canine impactions are bilateral. The displaced canine is placed palatal to the dental arch in 85 per cent of cases and labial/buccal in 15 per cent of cases (Ericson and Kurol, 1987) ${ }^{7}$.

The objectives of this study are to determine the skeletal and dentoalveolar parameters associated with palatal and buccal canine displacement using lateral cephalograms to compare subjects with buccally and palatally displaced canineswith control subjects who have normally erupting canines.

\section{MATERIALS AND METHODS}

This study was carried out on the available diagnostic (pre-treatment) lateral cephalograms available in the archive of Xraycenter (photon center). Records of 374 subjects with maxillary canine displacement (174 subjects palatally displaced, 200 buccally displaced) were used for this study. The diagnosis of the type of canine displacement was made using CBCT. The age of the subjects ranged between 13-15 years. Subjects were divided into two Groups : Group 1: maxillary palatal canine displacement and Group2 maxillary buccal canine displacement. All selected subjects had no missing teeth and no craniofacial abnormalities that may affect the shape or size of craniofacial structures. One hundred subjects with no maxillary canine displacement were selected to act as a control sample with normal occlusion and skeletal Class I. Lateral cephalograms were taken for each participant in centric occlusion.

Lateral skull radiographs Fig. (1 \& 2) were traced digitally using 25 cephalometric points and 9 cephalometric planes yielding 13 angular and 23 linear measurements were registered. Means and Standard deviations were calculated for all the measured variables. t-test was used to detect differences between groups studied. The P value was predetermined to 0.05 as the level of significance. 


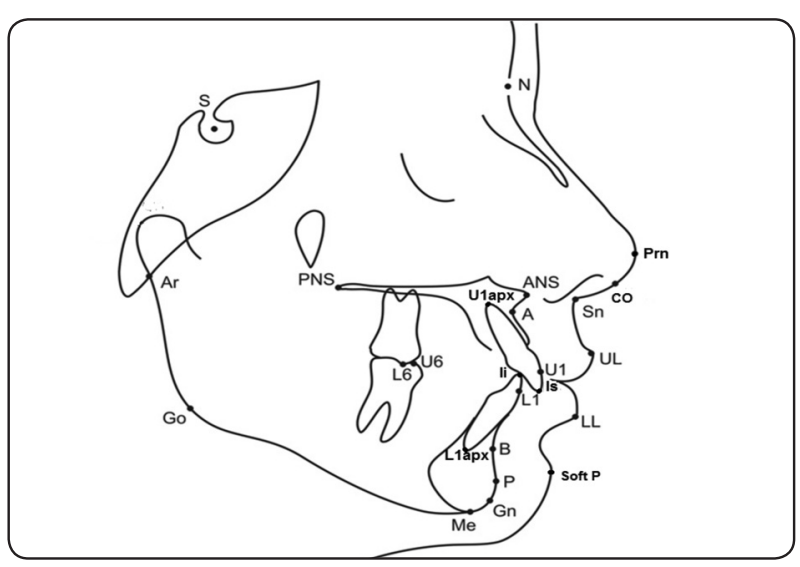

Fig. (1) Cephalometric points used in the analysis

\section{RESULTS}

The results showed that palatal and buccal canine displacement in the age 13-15 years occur most frequently in subjects with a class I skeletal classification (Table 1). Means, SDs and p values for theskeletal, dental and soft tissue variables for thepalatally and buccally displaced canine groups compared with the control in all age groups were shown in tables (2-4).

The result showed that there was a significant difference in the SNB angle betweenthe palatally displaced group and the control $(\mathrm{P}<0.05)$.The maxillary mandibular planes angle was smaller inthe palatally displaced canine group compared with the control group. This was statistically significant $(\mathrm{P}<0.05)$. The $\mathrm{SN}-\mathrm{Mn}$ angle was smaller inthe palatally displaced canine group compared with the control group $(\mathrm{P}<0.01)$.There was a significant difference in the lower and total anterior face height (LAFH, TAFH) between thepalatally

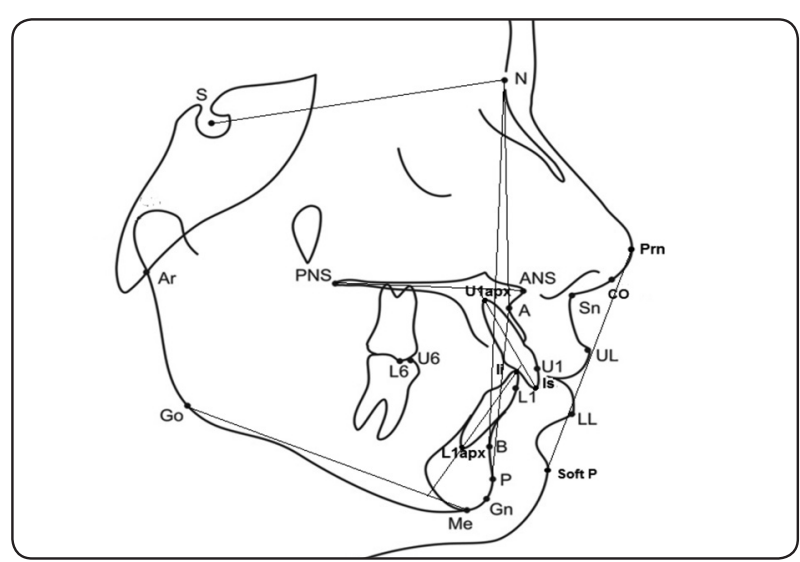

Fig. (2) Cephalometric planes used in the analysis

displacedcanine group and the control group $(\mathrm{P}<0.05, \mathrm{P}<0.01$ respectively). Palatally displaced canine group has shorter LAFH and TAFH compared to the control. The mandibular incisors were less protrudedin the palatally displaced canine group compared with the control group $(\mathrm{P}<0.05)$. The interincisal anglewas larger in the palatally displaced group compared with the control group $(\mathrm{P}<0.01)$.The overbite was significantly larger in the palatally displaced group compared with the control group $(\mathrm{P}<0.05)$.The upper and lower lips were retruded relative to the Esthetic linein the palatally displaced group compared with the control group $(\mathrm{P}<0.05, \mathrm{P}<0.01$, respectively). In table (2)

The results of cephalometric measurements of buccally displaced canine group and control group were shown in table (3). No significant differences were recorded regarding the buccally canine position with the variant antero- posterior skeletal classes versus the control group.

TABLE (1) The table is showing subjects' distribution of palatally and buccallydisplaced canines based on skeletal classification in age (13-15years).

\begin{tabular}{|c|c|c|c|c|c|c|}
\hline & \multicolumn{3}{|c|}{ Palatally displaced canines } & \multicolumn{3}{c|}{ Buccally displaced canines } \\
\hline & Class I & Class II & Class III & Class I & Class II & Class III \\
\hline Age 13-15 years & $41 \%$ & $33 \%$ & $26 \%$ & $48 \%$ & $38 \%$ & $14 \%$ \\
\hline
\end{tabular}


TABLE (2) Means, SDs, mean differences and p values for the skeletal, dental and soft tissue variables for the palatally displaced canine group compared with the control in age (13-15 years).

\begin{tabular}{|c|c|c|c|c|}
\hline Variable & $\begin{array}{c}\text { Palatally displacedgroup } \\
\text { Mean (SD) }\end{array}$ & $\begin{array}{l}\text { Control group } \\
\text { Mean (SD) }\end{array}$ & Mean Difference & $\mathrm{P}$ value \\
\hline SNA $\left({ }^{\circ}\right)$ & $82.70(3.29)$ & & 1.02 & 0.119 \\
\hline $\mathrm{SNB}\left({ }^{\circ}\right)$ & $79.86(3.38)$ & $78.35(4.29)$ & 1.52 & $0.028 *$ \\
\hline $\mathrm{ANB}\left({ }^{\circ}\right)$ & $2.84(2.41)$ & $3.30(2.22)$ & -0.46 & 0.263 \\
\hline $\mathrm{SN} . \mathrm{Mx}\left({ }^{\circ}\right)$ & $7.83(3.27)$ & $8.25(3.06)$ & -0.42 & 0.455 \\
\hline $\operatorname{SN} . \mathrm{Mn}\left({ }^{\circ}\right)$ & $33.15(5.72)$ & $35.90(5.99)$ & -2.74 & $0.009 * *$ \\
\hline Co.Sn.UL $\left(^{\circ}\right)$ & $99.23(10.36)$ & $97.54(10.37)$ & 1.70 & 0.358 \\
\hline $\operatorname{Mx} . \operatorname{Mn}\left({ }^{\circ}\right)$ & $25.33(5.70)$ & $27.65(4.88)$ & -2.33 & $0.015^{*}$ \\
\hline Ar.Go.Me $\left(^{\circ}\right)$ & $128.05(5.16)$ & $129.13(5.43)$ & -1.08 & 0.252 \\
\hline U1axis.NA $\left({ }^{\circ}\right)$ & $20.11(6.90)$ & $22.40(6.34)$ & -2.29 & 0.053 \\
\hline U1axis.Mx $\left({ }^{\circ}\right)$ & $110.39(6.98)$ & $112.33(6.74)$ & -1.94 & 0.114 \\
\hline U1axis.L1axis $\left(^{\circ}\right)$ & $131.49(11.89)$ & $125.59(10.72)$ & 5.90 & $0.004 * *$ \\
\hline L1axis.NB $\left({ }^{\circ}\right)$ & $25.80(7.06)$ & $28.82(6.63)$ & -3.02 & $0.014 *$ \\
\hline L1axis.Mn $\left({ }^{\circ}\right)$ & $92.79(7.58)$ & $94.42(7.72)$ & -1.63 & 0.232 \\
\hline Ar.Go.Me $\left(^{\circ}\right)$ & $128.05(5.16)$ & $129.13(5.43)$ & -1.08 & 0.252 \\
\hline TPFH (mm) & $71.26(5.33)$ & $70.82(4.83)$ & 0.44 & 0.623 \\
\hline TAFH $(\mathrm{mm})$ & $106.70(5.54)$ & $109.73(6.58)$ & -3.02 & $0.006 * *$ \\
\hline UAFH (mm) & $48.39(2.89)$ & $49.44(3.22)$ & -1.05 & 0.057 \\
\hline LAFH (mm) & $60.15(4.69)$ & $62.09(4.81)$ & -1.94 & $0.023 *$ \\
\hline LPFH (mm) & $44.16(4.24)$ & $42.91(4.10)$ & 1.25 & 0.092 \\
\hline Go-Gn(mm) & $67.33(4.91)$ & $67.98(4.15)$ & -0.66 & 0.415 \\
\hline Ar-Go (mm) & $44.16(4.24)$ & $42.91(4.10)$ & 1.26 & 0.092 \\
\hline $\operatorname{Ar}-\mathrm{Gn}(\mathrm{mm})$ & $99.75(6.01)$ & $99.89(5.61)$ & -0.14 & 0.892 \\
\hline $\operatorname{Ar}-\mathrm{ANS}(\mathrm{mm})$ & $82.03(5.24)$ & $82.23(4.46)$ & -0.19 & 0.822 \\
\hline $\operatorname{Ar}-\mathrm{A}(\mathrm{mm})$ & $79.49(5.00)$ & $79.89(4.53)$ & -0.40 & 0.635 \\
\hline ANS-PNS (mm) & $48.28(3.26)$ & $48.67(2.43)$ & -0.39 & 0.452 \\
\hline Wits $(\mathrm{mm})$ & $-3.92(3.39)$ & $-3.50(3.46)$ & -0.41 & 0.493 \\
\hline U6-Mx(mm) & $19.84(2.04)$ & $20.00(2.35)$ & -0.16 & 0.676 \\
\hline $\mathrm{U} 1-\mathrm{NA}(\mathrm{mm})$ & $5.16(1.94)$ & $5.44(1.81)$ & -0.28 & 0.409 \\
\hline Overjet(mm) & $2.80(2.13)$ & $2.92(1.88)$ & -0.12 & 0.735 \\
\hline Overbite $(\mathrm{mm})$ & $2.80(1.95)$ & $2.08(1.96)$ & 0.72 & $0.038 *$ \\
\hline L6-Mn (mm) & $26.97(2.62)$ & $27.80(2.17)$ & -0.84 & 0.052 \\
\hline L1-NB (mm) & $4.82(1.91)$ & $5.76(2.23)$ & -0.94 & $0.013^{*}$ \\
\hline Is-Mx(mm) & $25.79(2.70)$ & $26.38(2.64)$ & -0.59 & 0.214 \\
\hline $\mathrm{Ii}-\mathrm{Mn}(\mathrm{mm})$ & $37.26(2.99)$ & $38.21(2.51)$ & -0.95 & 0.054 \\
\hline Ii-Apog(mm) & $2.31(2.72)$ & $3.21(2.47)$ & -0.90 & 0.053 \\
\hline UL.Eline(mm) & $-3.11(2.32)$ & $-2.15(2.60)$ & -0.96 & $0.030 *$ \\
\hline LL-Eline (mm) & $-0.92(2.51)$ & $0.62(3.06)$ & -1.54 & $0.003 * *$ \\
\hline
\end{tabular}

$* \mathrm{P}<0.05, * * \mathrm{P}<0.01, * * * \mathrm{P}<0.001$ 
TABLE (3) Means, SD, mean differences and p values for the skeletal, dental and soft tissue variables for the buccally displaced canine group compared with the control in age (13-15 years).

\begin{tabular}{|c|c|c|c|c|}
\hline Variable & $\begin{array}{c}\text { Buccally displaced group } \\
\text { Mean (SD) }\end{array}$ & $\begin{array}{l}\text { Control group } \\
\text { Mean (SD) }\end{array}$ & Mean Difference & $\mathrm{P}$ value \\
\hline SNA $\left(^{\circ}\right)$ & $80.96(3.39)$ & $81.01(3.77)$ & -0.06 & 0.916 \\
\hline $\mathrm{SNB}\left({ }^{\circ}\right)$ & $77.33(3.85)$ & $77.24(3.88)$ & 0.09 & 0.876 \\
\hline $\mathrm{ANB}\left({ }^{\circ}\right)$ & $3.63(2.05)$ & $3.78(2.05)$ & -0.15 & 0.630 \\
\hline SN.Mx $\left(^{\circ}\right)$ & $8.33(3.45)$ & $8.71(3.21)$ & -0.38 & 0.449 \\
\hline SN.Mn $\left(^{\circ}\right)$ & $36.99(4.92)$ & $36.86(6.00)$ & 0.13 & 0.874 \\
\hline Co.Sn.UL $\left(^{\circ}\right)$ & $99.26(10.96)$ & $98.35(9.86)$ & 0.91 & 0.563 \\
\hline $\operatorname{Mx} . \operatorname{Mn}\left({ }^{\circ}\right)$ & $28.69(5.14)$ & $28.15(5.46)$ & 0.55 & 0.497 \\
\hline L1axis.NB $\left({ }^{\circ}\right)$ & $27.03(5.56)$ & $28.74(6.77)$ & -1.72 & 0.069 \\
\hline L1 axis.Mn $\left({ }^{\circ}\right)$ & $92.71(7.06)$ & $94.65(7.29)$ & -1.94 & 0.076 \\
\hline Ar.Go.Me $\left(^{\circ}\right)$ & $129.38(5.30)$ & $128.97(5.66)$ & 0.41 & 0.620 \\
\hline U1axis.NA $\left(^{\circ}\right)$ & $20.92(7.54)$ & $21.55(6.58)$ & -0.62 & 0.560 \\
\hline U1axis.Mx $\left({ }^{\circ}\right)$ & $110.18(7.31)$ & $111.28(6.63)$ & -1.10 & 0.298 \\
\hline U1axis.L1axis $\left({ }^{\circ}\right)$ & $128.42(10.55)$ & $125.93(11.03)$ & 2.49 & 0.129 \\
\hline TPFH (mm) & $70.92(4.66)$ & $70.72(4.76)$ & 0.20 & 0.784 \\
\hline TAFH (mm) & $110.41(6.21)$ & $110.51(6.03)$ & -0.10 & 0.915 \\
\hline LPFH (mm) & $43.02(3.74)$ & $42.80(3.98)$ & 0.22 & 0.702 \\
\hline LAFH (mm) & $63.15(4.36)$ & $62.67(4.89)$ & 0.49 & 0.490 \\
\hline $\mathrm{UAFH}(\mathrm{mm})$ & $49.21(3.40)$ & $49.84(2.64)$ & -0.63 & 0.170 \\
\hline Go-Gn(mm) & $66.73(5.09)$ & $67.73(4.47)$ & -1.00 & 0.167 \\
\hline Ar-Go (mm) & $43.08(3.73)$ & $42.80(3.98)$ & 0.28 & 0.629 \\
\hline $\operatorname{Ar}-\mathrm{Gn}(\mathrm{mm})$ & $98.88(6.15)$ & $99.40(5.53)$ & -0.51 & 0.559 \\
\hline $\operatorname{Ar}-\operatorname{ANS}(\mathrm{mm})$ & $81.56(4.88)$ & $82.40(4.60)$ & -0.84 & 0.246 \\
\hline $\operatorname{Ar}-\mathrm{A}(\mathrm{mm})$ & $79.06(4.70)$ & $79.83(4.70)$ & -0.78 & 0.277 \\
\hline ANS-PNS (mm) & $48.52(2.81)$ & $48.96(2.41)$ & -0.44 & 0.269 \\
\hline Wits (mm) & $-3.21(3.48)$ & $-2.84(3.04)$ & -0.37 & 0.457 \\
\hline UL.Eline (mm) & $-2.68(2.60)$ & $-2.23(2.61)$ & -0.45 & 0.256 \\
\hline $\mathrm{U6}-\mathrm{Mx}(\mathrm{mm})$ & $20.88(2.32)$ & $20.33(2.25)$ & 0.54 & 0.114 \\
\hline $\mathrm{U} 1-\mathrm{NA}(\mathrm{mm})$ & $5.24(1.75)$ & $5.37(1.57)$ & -0.13 & 0.601 \\
\hline Overjet(mm) & $3.21(2.01)$ & $3.23(1.84)$ & -0.02 & 0.941 \\
\hline Overbite (mm) & $2.31(2.30)$ & $2.53(1.97)$ & -0.23 & 0.482 \\
\hline L6-Mn (mm) & $27.41(2.17)$ & $28.09(2.58)$ & -0.68 & 0.063 \\
\hline L1-NB (mm) & $5.60(1.79)$ & $5.82(2.23)$ & -0.22 & 0.467 \\
\hline Is-Mx(mm) & $27.21(2.67)$ & $26.80(2.70)$ & 0.41 & 0.312 \\
\hline $\mathrm{Ii}-\mathrm{Mn}(\mathrm{mm})$ & $38.31(2.64)$ & $38.66(2.68)$ & -0.35 & 0.386 \\
\hline Ii-Apog(mm) & $2.65(2.27)$ & $3.04(2.52)$ & -0.39 & 0.275 \\
\hline UL.Eline (mm) & $-2.68(2.60)$ & $-2.23(2.61)$ & -0.45 & 0.256 \\
\hline LL-Eline (mm) & $-0.09(2.34)$ & $0.50(2.98)$ & -0.59 & 0.143 \\
\hline
\end{tabular}


TABLE (4) Means, SDs, mean differences and p values for the skeletal, dental and soft tissue variables for the palatally displaced canine group compared with the buccally displaced canine group in age (13-15 years).

\begin{tabular}{|c|c|c|c|c|}
\hline Variable & $\begin{array}{c}\text { Palatally canine group } \\
\text { Mean (SD) }\end{array}$ & $\begin{array}{l}\text { Buccally canine group } \\
\text { Mean (SD) }\end{array}$ & Mean Difference & $\mathrm{P}$ value \\
\hline SNA $\left(^{\circ}\right)$ & $82.70(3.29)$ & $80.96(3.39)$ & 1.74 & $0.002 * *$ \\
\hline $\mathrm{SNB}\left({ }^{\circ}\right)$ & $79.86(3.38)$ & $77.32(3.85)$ & 2.53 & $0.000 * * *$ \\
\hline $\operatorname{ANB}\left({ }^{\circ}\right)$ & $2.84(2.41)$ & $3.63(2.05)$ & -0.79 & $0.034 *$ \\
\hline $\operatorname{SN} . M x\left({ }^{\circ}\right)$ & $7.83(3.27)$ & $8.33(3.44)$ & -0.50 & 0.372 \\
\hline $\mathrm{SN} \cdot \mathrm{Mn}\left({ }^{\circ}\right)$ & 33.15 (5.72) & 36.99 (4.93) & -3.84 & $0.000 * * *$ \\
\hline Co.Sn.UL( $\left(^{\circ}\right)$ & $99.23(10.36)$ & $99.26(10.96)$ & -0.03 & 0.987 \\
\hline $\operatorname{Mx} \cdot \operatorname{Mn}\left({ }^{\circ}\right)$ & $25.32(5.70)$ & $28.69(5.14)$ & -3.37 & $0.000 * * *$ \\
\hline Ar.Go.Me $\left({ }^{\circ}\right)$ & $128.05(5.16)$ & $129.38(5.30)$ & -1.33 & 0.132 \\
\hline U1axis.NA $\left(^{\circ}\right)$ & $20.11(6.90)$ & $20.92(7.54)$ & -0.81 & 0.505 \\
\hline U1axis.Mx $\left({ }^{\circ}\right)$ & $110.39(6.98)$ & $110.18(7.31)$ & 0.21 & 0.860 \\
\hline U1axis.L1axis $\left(^{\circ}\right)$ & 131.49 (11.89) & $128.42(10.55)$ & 3.07 & 0.102 \\
\hline L1axis.NB $\left({ }^{\circ}\right)$ & $25.80(7.06)$ & $27.03(5.56)$ & -1.22 & 0.244 \\
\hline L1axis.Mn $\left({ }^{\circ}\right)$ & $92.79(7.58)$ & $92.71(7.06)$ & 0.08 & 0.949 \\
\hline TPFH (mm) & $71.26(5.33)$ & $70.92(4.66)$ & 0.34 & 0.679 \\
\hline TAFH (mm) & $106.70(5.54)$ & $110.41(6.21)$ & -3.71 & $0.000 * * *$ \\
\hline UAFH (mm) & $48.39(2.89)$ & $49.21(3.40)$ & -0.82 & 0.130 \\
\hline LPFH (mm) & $44.16(4.24)$ & $43.02(3.74)$ & 1.14 & 0.088 \\
\hline LAFH (mm) & 60.15 (4.69) & $63.15(4.37)$ & -3.00 & $0.000 * * *$ \\
\hline Go-Gn(mm) & $67.33(4.91)$ & 66.73 (5.09) & 0.60 & 0.478 \\
\hline Ar-Go (mm) & $44.16(4.24)$ & $43.08(3.73)$ & 1.08 & 0.105 \\
\hline $\operatorname{Ar}-\mathrm{Gn}(\mathrm{mm})$ & $99.75(6.01)$ & $98.88(6.15)$ & 0.87 & 0.395 \\
\hline $\operatorname{Ar}-\operatorname{ANS}(\mathrm{mm})$ & $82.03(5.24)$ & $81.56(4.88)$ & 0.47 & 0.580 \\
\hline $\operatorname{Ar}-\mathrm{A}(\mathrm{mm})$ & $79.49(5.00)$ & $79.06(4.70)$ & 0.43 & 0.594 \\
\hline ANS-PNS (mm) & $48.28(3.26)$ & $48.52(2.81)$ & -0.24 & 0.636 \\
\hline Wits (mm) & $-3.92(3.38)$ & $-3.21(3.48)$ & -0.71 & 0.224 \\
\hline $\mathrm{U} 6-\mathrm{Mx}(\mathrm{mm})$ & $19.84(2.04)$ & $20.88(2.32)$ & -1.04 & $0.005^{* *}$ \\
\hline $\mathrm{U} 1-\mathrm{NA}(\mathrm{mm})$ & $5.16(1.94)$ & $5.24(1.75)$ & -0.07 & 0.817 \\
\hline Overjet(mm) & $2.80(2.13)$ & $3.21(2.01)$ & -0.41 & 0.240 \\
\hline Overbite $(\mathrm{mm})$ & $2.80(1.95)$ & $2.31(2.30)$ & 0.49 & 0.172 \\
\hline L6-Mn (mm) & $26.97(2.62)$ & $27.41(2.17)$ & -0.44 & 0.265 \\
\hline L1-NB (mm) & $4.82(1.91)$ & $5.60(1.79)$ & -0.78 & $0.013 *$ \\
\hline Is-Mx(mm) & $25.79(2.70)$ & $27.21(2.67)$ & -1.42 & $0.002 * *$ \\
\hline $\mathrm{Ii}-\mathrm{Mn}(\mathrm{mm})$ & $37.26(2.99)$ & $38.31(2.64)$ & -1.04 & $0.028 *$ \\
\hline Ii-Apog(mm) & $2.31(2.72)$ & $2.65(2.27)$ & -0.34 & 0.418 \\
\hline UL.Eline(mm) & $-3.11(2.32)$ & $-2.68(2.60)$ & -0.43 & 0.302 \\
\hline LL-Eline (mm) & $-0.92(2.50)$ & $-0.09(2.34)$ & -0.82 & $0.043^{*}$ \\
\hline
\end{tabular}

$* P<0.05, * * P<0.01, * * * P<0.001$ 
The results showed that SNA and SNB angles were larger in the palatally displaced canine group compared with the buccally displaced canine group $(\mathrm{P}<0.01, \mathrm{P}<0.001$ respectively). The ANB angle was smallerin the palatally displaced canine group compared with the buccally displaced canine group $(\mathrm{P}<0.05)$.The maxillary mandibular planes angle and $\mathrm{SN}-\mathrm{Mn}$ angle were smaller in the palatally displaced canine group compared with the buccally displaced canine group $(\mathrm{P}<0.001)$. The total anterior face height and lower anterior face height (TAFH, LAFH) were significantly smaller in the palatally displaced canine group compared with the buccally displaced canine group $(\mathrm{P}<0.001)$. The mandibular incisors were less protruded (L1-NB) in the palatally displacedcanine group compared with the buccally displaced canine group $(\mathrm{P}<0.05)$. The maxillary anterior dentoalveolar height (Is-Mx), the maxillary posterior dentoalveolar height (U6-Mx) and the mandibular anterior dentoalveolar height (Ii-Mn) were significantly smaller in the palatally displaced canine group compared with the buccally displaced canine group $(\mathrm{P}<0.01, \mathrm{P}<0.01, \mathrm{P}<0.05$ respectively $)$. The lower lip was retruded relative to the Esthetic linein the palatally displacedcanine group compared with the buccally displaced canine group $(\mathrm{P}<0.05)$. (Table 4).

\section{DISCUSSION}

The purpose of this study was to identify the skeletal and dentoalveolar features associated with maxillary canine displacement. This study was carried out on a relatively large number of subjects. The age of the subjects varied from 13-15 years. included subjects during or few years after their growth spurts. The studied and control groups were matched also by age and type of malocclusion (based on the skeletal classification). The results of the present study show that palatal canine displacement in the age 13-15 occurs most frequently in subjects with a class I skeletal relationship. The prevalence rates of sagittal skeletal relationships for subjects with palatally displaced canines in this study were 71 class I subjects (41\%), 62 class II subjects (36\%) and 41 class III subjects (24\%). This was in agreement with Sacerdoti and Baccetti (2004) ${ }^{18}$ who reported that the prevalence rates of sagittal skeletal relationships in subjects with palatally displaced canines were 52 per cent class I, 31 per cent class II and 17 per cent class III, and that these data reproduce closely the standard prevalence rates for the three sagittal skeletal classes in orthodontic populations. Also, based on incisor classification, a palatally displaced canine has been reported to occur most frequently in Class II division 2 malocclusions (Basdra et al., 2000;19 Al-Nimri and Gharaibeh, $2005^{20}$. However, Brin et al. $(1986)^{21}$ reported 73 per cent of subjects with palatally displaced canines presented with Class I, 20 per cent with Class II, and 7 per cent with Class III. In this study, buccal canine displacement has been shown to occur most frequently in subjects with a class I skeletal classification. The sagittal skeletal relationships in subjects with buccally displaced canines were 88 class I subjects (44\%), 78 class II subjects (39\%) and 34 class III subjects $(17 \%)$. There are no previous studies looked at the sagittal skeletal relationships in association with buccally displaced canines.

Regarding the lengths of mandible, mandibular body and ramus of mandible and the distances between (Ar) and (ANS), (Ar) and (A) point in subjects with maxillary canine displacement. The length of the mandible (Ar-Gn) and the length of the ramus of the mandible (Ar-Go) were not significantly larger in the palatally displaced canine group compared with the control group, and the length of the body of mandible (Go-Gn) was also larger but statistically not significant. There is no significant difference in the maxillary length between subjects with buccally andpalatally displaced canines and the control group. The finding of this study was agree with that reported by Larsen et al. $(2010)^{22}$ that there is no significant difference in the ANSPNS length between subjects with maxillary canine 
displacement (combined palatal and buccal subjects together) and the control subjects. The maxillary mandibular planes angle, the total anterior face height and the lower anterior face height were significantly smaller in subjects with palatally displaced canines compared with the control group. This was in agreement with Sacerdotiand Baccetti $(2004)^{18}$ who revealed a significant association between vertical craniofacial features and palatally displaced canines.

Subjects with palatally displaced canines had retroclined maxillary and mandibular incisors. This can be explained by the higher prevalence rate of palatally displaced canines in Class II division 2 malocclusions (Basdra et al., 2000) ${ }^{19}$. An increased prevalence of an occlusal deep bite characteristic has been described in palatally displaced canine subjects (Leifert and Jonas, 2003) ${ }^{23}$. In this study, the overbite was increased in subjects with palatally displaced canines compared with the control. The upper and lower lips were retruded relative to the Esthetic line in subjects with palatally displaced canines. The Nasolabial angle was larger in subjects with palatally displaced canines. However, as the majority of subjects with palatally displaced canines had retroclined upper incisors.

\section{CONCLUSIONS}

1) Palatal and buccal canine displacement has been shown to occur most frequently in subjects with a class I skeletal relationship.

2) There in is no significant difference in maxillary length between subjects with buccally and palatally displaced canine and control group.

3) There in is no significant difference in the length of the mandible and the length of the ramus of the mandible in palatally displaced caninecompared with the control group.

4) The maxillary mandibular planes angle, the total anterior face height and the lower anterior face height were significantly smaller in subjects with palatally displaced canines compared with the control.

5) Subjects with palatally displaced canines had retroclined maxillary and mandibular incisors.

6) The overbite was increased in the subjects who have palatally displaced canines compared with the control.

7) The maxillary anterior dentoalveolar height, the maxillary posterior dentoalveolar height and the mandibular anterior dentoalveolar height were small in subjects with palatally displaced canines compared with bucally displaced canines

8) The upper and lower lips were retruded relative to the Esthetic line and the Nasolabial angle was larger in subjects with palatally displaced canines.

\section{REFERENCES}

1- McSherry, P., Richardson, A. Ectopic eruption of the maxillary canine quantified in three dimensions on cephalometric radiographs between the ages of 5 and 15 years. Eur J Orthod.1999; 21, 41-48.

2- Shah, R. M., Boyd, M. A., Vakil, T. F. Studies of permanent tooth anomalies in 7886 Canadian individuals. J Can Dent Assoc.1978; 44, 262-264.

3- Thilander, B. and Jakobsson, S. Local factors in impaction of maxillary canines. In: ActaOdontol Scand.1968; 26 $145-168$

4- Suri, L., Gagari, E. and Heleni, V. Delayed tooth eruption: Pathogenesis, diagnosis, and treatment. A literature review. In: Am J OrthodDentofacial Orthop.2004; 126 432-445.

5- Peck, S., Peck, L. and Kataja, M.The palatally displaced canine as a dental anomaly of genetic origin. In: Angle Orthod.1994; 64, 249-56.

6- Rajic, S., Muretic, Ž.,Percac, S. Impacted canine in a prehistoric skull. Angle Orthod.1996;66, 477 - 480.

7- Ericson, S., Kurol, J. Radiographic examination of ectopically erupting maxillary canines. Am J OrthodDentofacial Orthop.1978; 91, 483-92. 
8- Jacoby, H. J.The etiology of maxillary canine impactions. Ama J Orthod.1983; 84 (2).125-132.

9- Zilberman, Y., Cohen, B. and Becker, A. Familial trends inpalatal canines, anomalous lateral incisors, and related phenomena.Eur J Orthod.1990; 12, 135 - 139.

10- Peck, S., Peck, L. and Kataja, M. Prevalence of tooth agenesis and peg shaped maxillary lateral incisor associated with palatally displaced canine (PDC) anomaly. Ame J OrthodDentofacialOrthop. 1996;110, 441 - 443.

11- Sambataro, S., Baccetti, T., Franchi, L., Antonini, F. Early predictive variables for upper canine impaction as derived from posteroanteriorcephalograms. Angle Orthod.2005; $75,28-34$.

12- Moyers, R. E. Handbook of orthodontics, 2nd ed. 1963; Chicago, Year Book Medical Publishers, Inc.

13- Dachi, S. F. and Howell, F.V. (1961).A survey of 3,874 routine full-mouth radiographs.Oral Surg Oral Med Oral Pathol. 14, 1165-1169.

14- Thilander, B. and Myrberg, N.The prevalence of malocclusion in Swedish school children.Scand J Dent Res. 1973;81, 12-20.

15- Shah, R. M., Boyd, M.A., Vakil, T. F. Studies of permanent tooth anomalies in 7886 Canadian individuals. J Can Dent Assoc.1978; 44, 262-264

16- Kuftinec, M. M., Stom, D. and Shapira, Y. The impacted maxillary canine: I. Review of concepts. ASDC J Dent Child.1995;62(5), 317-324.
17- McConnell, T. L., Hoffman, D. L., Forbes, D. P., Jensen, E. K. and Wientraub, N. H. Maxillary canine impaction in patients with transverse maxillary deficiency. J Denti Child.1996; 63, 190-195.

18- Sacerdoti, R. and Baccetti, T. Dentoskeletal Features Associated with Unilateral or Bilateral Palatal Displacement of Maxillary Canines. Angle Orthod.2004; 74, 725-732.

19- Basdra, E. K., Kiokpasoglou, M. and Stellzig, A. The Class II division 2 craniofacial type is associated with numerous congenital tooth anomalies. Eur J Orthod.2000; 22, 529535 .

20- Al-Nimri, K. and Gharaibeh, T. Space conditions and dental and occlusal features in patients with palatally impacted maxillary canines: an aetiological study. Eur J Orthod .2005; 27, 461-465.

21- Brin, I., Becker, A. and Shalhav, M. Position of the maxillary permanent canine in relation to anomalous or missing lateral incisors: a population study. Eur J Orthod. 1986; 8, 12-6.

22- Larsen, H. J., Sorensen, H. B., Artmann, L., Christensen, I. J., and Kjaer, I. Sagittal, vertical and transversal dimensions of the maxillary complex in patients with ectopic maxillary canines. OrthodCraniofac Res.2010; 13, 34-39.

23- Leifert, S. and Jonas, E. Dental anomalies as a microsymptom of palatal canine displacement. J Orofac Orthop.2003; 64, 108-20 